\title{
THE INFLUENCE OF WORKERS' HEALTH STATUS ON EMPLOYERS' DECISION-MAKING DURING PERSONNEL RESTRUCTURING IN A TYPICAL PUBLIC LIMITED ENTERPRISE IN SLOVENIA VPLIV ZDRAVSTVENEGA STANJA DELAVCEV NA ODLOČANJE DELODAJALCA MED PROCESOM KADROVSKEGA PRESTRUKTURIRANJA ZNAČILNE DELNIŠKE DRUŽBE V SLOVENIJI
}

\author{
Andrea MARGAN ${ }^{* *}$, Metoda DODIČ-FIKFAK²
}

1'Department of Occupational, Traffic and Sports Medicine, Medical Center Ptuj, Potrceva 19a, Ptuj, Slovenia ${ }^{2}$ Institute of Occupational, Traffic and Sports Medicine, University Medical Center, Poljanski nasip 58, Ljubljana, Slovenia

\section{ABSTRACT}

Keywords: sick leave, disability category, medical certificates, health selection, personnel restructuring
Objectives. Alongside individual indicators of job performance, even workers' health status could be a criterion for selection. The mechanisms for health selection are a reduction of productivity in relation to illness or certain health behaviour. The aim of the study was to establish how indicators of workers' health status, which are accessible to the employer, influence the employer's decision-making on which workers to retain and which to dismiss during personnel restructuring in the enterprise.

Methods. Due to a planned closure of a plant, the observed company began personnel restructuring which included a strategic decrease in the number of employees and the relocation of workers within the company. Two nested case control studies were conducted. The cases were divided into two groups and defined as follows: employees who were relocated and employees whose employment contract was terminated.

Results. The results show that the disability category and long-time sick leave exert the greatest influence on the employer's decision on the selection of workers. Workers with work-related disability have lower odds to be relocated to a new workplace (OR=0.5; $95 \% \mathrm{Cl} 0.2$ to 1.1 ) and higher odds to be dismissed $(\mathrm{OR}=6.51 ; 95 \% \mathrm{Cl} 3.33$ to 12.72$)$. The workers with a history of a long-time sick leave also have lower odds to be relocated $(\mathrm{OR}=0.31 ; 95 \% \mathrm{Cl} 0.11$ to 0.88$)$ and higher odds to be dismissed $(\mathrm{OR}=4.32$; $95 \% \mathrm{Cl} 2.08$ to 8.96 ).

Conclusions. Indicators of health which were accessible to the employer actually exerted influence on the employer's decision-making, which could show a direct form of health selection.

Izhodišča. V času gospodarskega prestrukturiranja in krize je veliko delavcev odpuščenih ali premeščenih na nova delovna mesta. Na odločitev delodajalca, koga bo odpustil in koga premestil, lahko vpliva tudi zdravje delavca. Cilj raziskave je ugotoviti, kako objektivni kazalci zdravstvenega stanja delavcev, do katerih ima delodajalec dostop, vplivajo na odločanje, kdo bo premeščen na drugo delovno mesto in kdo odpuščen.

Metode. Značilno slovensko podjetje s 1000 zaposlenimi je v letu 2005 začelo kadrovsko prestrukturiranje, ki je vključevalo zmanjševanje števila zaposlenih in premeščanje na druga delovna mesta znotraj podjetja. Narejeni sta bili dve vgnezdeni študiji primerov s kontrolami. Kot primera sta bili definirani dve skupini delavcev: tisti, ki jih je delodajalec $v$ opazovanem obdobju premestil na drugo delovno mesto in tisti, ki jim je odpovedal pogodbo o zaposlitvi iz poslovnega razloga. Kontrole so bili delavci iz preostale kohorte, usklajeni po socialnem statusu, spolu in starosti.

Rezultati. Rezultati kažejo, da na odločitev delodajalca o izbiri delavcev najbolj vplivata kategorija invalidnosti in dolgotrajni bolniški stalež. Delovni invalidi imajo manjše obete, da bodo premeščeni na novo delovno mesto ( $R O=0.5$; $95 \%$ IZ 0.2-11), in večje, da bodo odpuščeni ( $R O=6.51 ; 95 \%$ IZ 3.33-12.72). Tudi delavci, ki so bili $v$ bolniškem staležu $\geq 30$ dni, imajo manjše obete, da bodo premeščeni $(R O=0.31$; $95 \%$ IZ 0.11-0.88), in večje, da bodo odpuščeni (RO=4.32; 95\% IZ 2.08 - 8.96).

Zaključek. V raziskavi smo dokazali, da kazalniki zdravja, do katerih ima dostop delodajalec, vplivajo na odločanje delodajalca $v$ procesu prestrukturiranja podjetja, kar kaže na neposredno obliko selekcije zaradi zdravstvenega stanja.

*Corresponding author: Tel: +386 278715 78; E-mail: andrea.margan@gmail.com 


\section{INTRODUCTION}

The decline in economic activity in Slovenia during the crisis was among the largest in the EU. Several years of unfavourable economic conditions have brought a significant deterioration in the situation on the labour market, which, alongside the cuts in pension and social benefits in 2012, has deepened the decline in disposable income in the last few years and hence the material welfare of households. This situation largely contributed to an increasing unemployment rate.

When deciding which workers could contribute to higher productivity, employers, as a rule, take into consideration individual indicators of job performance, such as education, personal characteristics, experience; this is referred to as the positive selection of workers (1). The question is posed whether the employers' decision on which workers to retain and which to dismiss is based on their health at the time when labour supply exceeds demand. In this case, the workers' health would be the criterion for the selection.

Due to personal data protection, employers usually do not know how healthy or sick the employees are; that is why their decisions are based on the health indicators accessible to them. These are: sick leave, disability category and approved occupational doctor's certificate (medical certificate). The medical certificate is a document with which an occupational doctor confirms whether the worker fulfils special health requirements for the performance of a particular work after $s /$ he has carried out a preventive medical check-up. A worker's workability is assessed as follows: workability without restrictions, workability with a restriction, temporary or permanent incapacity to work. The occupational doctor can also propose in his/her certificate that workability should be assessed by the Invalidity Committee of the Pension and Disability Insurance Institute of Slovenia.

On the basis of these indicators, employers can assess the worker's workability and can presuppose what influence these indicators will have on the operational effectiveness and, indirectly, also on the business results of a company. The indicators of workers' ill health can represent a sign of lower operational effectiveness for the employer, resulting in direct absence from the work process (sick leave) or, indirectly, they can refer to the limitations in the complete performance (disability and restrictions at work), resulting in the absence of achieving the expected goals $(2,3)$.

As it is presumed that, in the course of restructuring, the decision of management which workers will be relocated to another workplace and which workers will be dismissed, depends on the health status of the employees, the aim of our study was to find out how objective indicators of workers' health status (sick leave, approved medical practitioner's certificate and disability category) influence the employer's decision-making concerning personnel restructuring (the relocation of workers within the company and termination of employment relationship) of a typical Slovene public limited company.

\section{METHODS}

\subsection{Study Population}

The observed population consisted of the employees of a typical public limited company with more than 1000 employees, the company belonging to the non-ferrous metal industry. The company has been chosen because one of the researchers (otherwise employed in a public medical centre) is carrying out duty as the occupational doctor for the enterprise. Due to a planned closure of a plant (in 2008), the company began personnel restructuring as early as 2005 , the restructuring which included a strategic decrease in the number of employees and the relocation to other workplaces within the company. The peak was reached in 2009, with the occurrence of the economic crisis. The initial observed population is comprised of 885 workers who were employed in the observed company on a permanent basis on January 1, 2005, for at least a year. The workers whose employment contract was suspended or terminated on fault-based grounds were excluded from the observed population. The observed period was from January 1, 2005, to December 31, 2010. The data were abstracted from administrative records. Ethical approval for the study was obtained from the Republic of Slovenia National Medical Ethics Committee, Ljubljana.

\subsection{Study Design}

Two nested case control studies were carried out.

The first case control study: Relocation to a different workplace

- The cases are defined as employees who were relocated to a different workplace by the employer in the observed period.

- For one case of a relocated worker, two controls were chosen, which were matched by sex, age, position in the workplace (blue and white collar workers), and were employed at the time when the relocation of the case took place.

The second case control study: Termination of employment relationship

- The cases are defined as employees whose employment contract was terminated for business purposes.

- For one case of a dismissed worker, four controls were chosen, which were matched by sex, age, position in the workplace (blue and white collar workers), and 
were employed at the time when the dismissal of the case took place.

In both case control studies, the same outcomes were observed: sick leave and approved medical certificate (the limitation of workability and proposal for the assessment of the remaining workability at the Invalidity Committee) and the already recognized disability category.

We wanted to establish how the employer's decision was influenced by the frequency, duration and seriousness of sick leave in the year prior to the change in the employment relationship. The frequency of sick leave was defined as the number of cases of sick leave per person, the duration of sick leave as the number of days of sick leave per person, and seriousness was defined as the number of days of sick leave per one case of sick leave. Sick leave was divided into three classes depending on its duration, namely: total sick leave (all cases of sick leave independent of the duration of (an) individual case); sick leave $\leq 5$ days (only those cases of sick leave that lasted equal to or fewer than five days), and sick leave $\geq 30$ days (only those cases of sick leave that lasted for thirty days or more). For each class, the percentage, frequency, duration and seriousness of sick leave were calculated.

The results of the medical certificate were divided into two groups: workers without restrictions of workability and workers with a restricted workability. The group of workers with a restricted workability also included workers with an established temporary or permanent incapacity to perform current work.

In Slovenia, workers with work-related disability were eligible for disability pension benefits which were granted by the Pension and Disability Insurance Institute of Slovenia. The disability is classified into three categories. The first category means disability retirement (loss of work capacity). The second and third disability categories mean that a worker can still work with some limitation. The second disability category includes insured persons whose work capacity for their own profession is reduced by 50 per cent or more, and the third disability category includes insured persons who, with or without professional rehabilitation, are no longer capable of a full-time work, but can perform certain work at least part-time, or whose work capacity for their own profession is reduced by less than 50 per cent, or who can still work in their profession full-time, but cannot perform the work to which they are assigned.

When assessing the influence of the disability pension, only the second and the third disability categories were taken into consideration, the categories obtained prior to the change in the employment relationship (relocation/ dismissal). All test subjects falling within the second and third disability categories were treated as one group.
As confounders, the following was taken into consideration: the level of education, smoking, diagnoses related to alcohol abuse and body mass index.

\subsection{Data Collection}

The data on the employees who represented the initial observed population $(\mathrm{n}=885)$ were obtained for each year separately (2005-2010), from two databases at the human resources department of the company. Data collection was exactly the same in both case control studies, which were checked manually for each year separately. The workers left the company for different reasons: death, retirement at retirement age, disability retirement, dismissal by mutual agreement, employment contract was suspended or terminated on fault-based grounds.

For each case and control, the data was collected on sick leave for each month separately, 12 months prior to the change regarding the date of the change in the employment contract. The month prior to the change in the employment relationship was excluded because this is the time usually needed for the administrative procedures necessary for the relocation of a worker. The duration of sick leave is presented in working days and is calculated on the basis of man-hours. If the absence from work did not exceed four hours, it was not taken into consideration. Regarding the length of sick leave expressed in working days, sick leave was divided into three classes, according to the method of the organization of health insurance in the case of sick leave, duration of the working week (40 hours/week), and our presupposition that a longer sick leave would be a better indicator of ill health or illness, while non-medical (social and personal) circumstances exert a greater influence on shorter sick leave (fewer than 5 days) (4-10).

The occupational medicine health record served as the basis for obtaining a medical certificate with the assessment of fulfilling special health demands after the performed preventive medical check-up needed for a particular workplace and the medical practitioner's proposal for the assessment of the remaining workability by the Invalidity Committee. The assessments of the last preventive medical check-up prior to the change in the employment relationship were taken into consideration. The occupational medicine health record also served as a basis for the smoking status, diagnoses related to alcohol abuse and body mass index at the time of the last checkup for all the cases and controls.

\subsection{Data Analysis}

Data analysis was exactly the same in both case control studies. All analyses were performed with IBM SPSS Statistics 21.0. package. Standard descriptive statistics 
was followed by the calculation of differences in the frequency of values of variables or differences in mean values between the cases (relocated, dismissed) and controls using the t-test and Chi-square test. Differences in the share, frequency, duration and seriousness of sick leave (total sick leave, sick leave $\leq 5$ days and sick leave $\geq 30$ days), in the restrictions of workability, proposals for the assessment of the remaining workability by the Invalidity Committee, as well as disability categories were tested. A further analysis focused on the connection between an individual variable and the possibility that a worker would be relocated or dismissed. Univariate logistic analysis was followed by multivariate logistic analysis, or the formation of models for testing the hypothesis about the causal association between the relocation or dismissal (dependent variable) and independent variables. Conditional logistic regression was used in the calculation. The causal relationship was defined as the likelihood (OR; $95 \% \mathrm{Cl}$ ) that the employer decides for the relocation of a worker to a new workplace, or for the termination of the employment relationship.

\section{RESULTS}

From the initial population $(n=885), 231$ cases and 602 controls were chosen. In the initial population, $90 \%$ were men, $69 \%$ of them were blue collar workers, who were 43 years old on average and had been employed for 23 years (20 years in the observed public limited company). In the observed period from January 1, 2005, to December 31, 2010, 161 workers were relocated, most of them in 2009 (29\%). In the same period, 70 workers were dismissed, most of them in 2010 (44\%) (Table 1). The majority of the relocated $(78 \%)$ and dismissed $(80 \%)$ workers were male production workers. The majority of the workers employed in the company were male $(85 \%), 73 \%$ of them being blue collar workers. ${ }^{1}$

Table 1. Relocated and dismissed workers from 2005 to 2010.

\begin{tabular}{lcc}
\hline OBSERVED PERIOD & $\begin{array}{c}\text { RELOCATED } \\
(\mathbf{n}=161)\end{array}$ & $\begin{array}{c}\text { DISMISSED } \\
(\mathbf{n}=\mathbf{7 0})\end{array}$ \\
\hline $\begin{array}{l}\text { January 1, 2005 - } \\
\text { December 31, 2005 }\end{array}$ & 10 & 2 \\
$\begin{array}{l}\text { January 1, 2006 - } \\
\text { December 31, 2006 }\end{array}$ & 37 & 2 \\
$\begin{array}{l}\text { January 1, 2007 - } \\
\text { December 31, 2007 }\end{array}$ & 23 & 8 \\
$\begin{array}{l}\text { January 1, 2008 - } \\
\text { December 31, 2008 } \\
\text { January 1, 2009 - }\end{array}$ & 31 & 23 \\
$\begin{array}{l}\text { December 31, 2009 } \\
\text { January 1, 2010 - }\end{array}$ & 47 & 4 \\
December 31, 2010 & 13 & 31 \\
\hline
\end{tabular}

In comparison to the relocated workers, a significantly longer duration $(p=0.032)$ and greater seriousness of total sick leave $(p<0.001)$ can be observed in dismissed workers: they have significantly more $(p<0.001)$ long-time sick leave (sick leave $\geq 30$ days), restrictions of workability $(p<0.001)$, proposals for the assessment of the remaining workability $(p<0.001)$, as well as the disability category $(p<0.001)$ (Table 2).

Table 2. Cases (relocated and dismissed workers) by percentage of sick leave, restriction of workability, proposal for the assessment of the remaining workability and disability category.

\begin{tabular}{lccccc}
\hline & $\begin{array}{c}\text { RELOCATED } \\
(\mathbf{n}=\mathbf{1 6 1})\end{array}$ & \multicolumn{2}{c}{$\begin{array}{c}\text { DISMISSED } \\
(\mathbf{n}=\mathbf{7 0})\end{array}$} & \\
\hline VARIABLE & $n$ & $\%$ & $n$ & $\%$ & $p$ Value \\
Sick leave & 100 & 62.1 & 44 & 62.9 & 0.914 \\
$\begin{array}{l}\text { Restriction of } \\
\text { workability }\end{array}$ & 27 & 16.8 & 37 & 52.9 & $<0.001$ \\
$\begin{array}{l}\text { Proposal for the } \\
\text { assessment of }\end{array}$ & 6 & 3.7 & 22 & 31.5 & $<0.001$ \\
$\begin{array}{l}\text { workability } \\
\begin{array}{l}\text { Disability category } \\
\hline\end{array}\end{array}$ & 8 & 4.96 & 30 & 42.8 & $<0.001$ \\
\hline
\end{tabular}

\subsection{The First Case Control Study: Relocation to a Different Workplace}

\subsubsection{Descriptive Statistics}

The average age of the relocated workers (cases) was 41 , and the average employment period is 20 years, almost 19 , in the company. At the time of the relocation of the cases, the average employment period of the controls was 21 years, and the average duration of the employment in the company amounted to 18 years.

In the observed period, $62 \%$ of the relocated workers and $61 \%$ of the controls were on sick leave. There are no significant differences between the relocated workers and controls in the share of workers who were on sick leave (Table 3), in the frequency, duration and seriousness of total sick leave.

${ }^{1}$ The data of the personnel department from January 1, 2005. 
Table 3. Cases (relocated workers) and controls by percentage of sick leave, restriction of workability, proposal for the assessment of the remaining workability and disability category.

\begin{tabular}{|c|c|c|c|c|c|}
\hline \multirow[b]{2}{*}{ VARIABLE } & \multicolumn{2}{|c|}{$\begin{array}{l}\text { RELOCATED } \\
(n=161)\end{array}$} & \multicolumn{2}{|c|}{$\begin{array}{l}\text { DISMISSED } \\
(\mathrm{n}=322)\end{array}$} & \multirow[b]{2}{*}{$p$ Value } \\
\hline & $n$ & $\%$ & $n$ & $\%$ & \\
\hline Sick leave & 100 & 62.1 & 195 & 60.6 & 0.741 \\
\hline $\begin{array}{l}\text { Restriction of } \\
\text { workability }\end{array}$ & 27 & 16.8 & 51 & 15.8 & 0.793 \\
\hline $\begin{array}{l}\text { Proposal for the } \\
\text { assessment of } \\
\text { workability }\end{array}$ & 6 & 3.7 & 14 & 4.3 & 0.747 \\
\hline Disability category & 8 & 4.96 & 30 & 9 & 0.094 \\
\hline
\end{tabular}

In comparison to the controls, a significantly lower $(p=0.028)$ share of the relocated workers were on longtime sick leave (sick leave $\geq 30$ days). There were no significant differences in the frequency, duration and seriousness of short-time sick leave (sick leave $\leq 5$ days) between the relocated workers and controls. The frequency $(p=0.029)$ and duration $(p=0.027)$ of long-time sick leave (sick leave $\geq 30$ days) were significantly lower in the group of relocated workers.

There were no significant differences between the relocated workers and controls in the number of restrictions of workability, proposals for the assessment of the remaining workability and the number of recognized disability categories (Table 3 ).

\subsubsection{Univariate Logistic Analysis}

As expected, the results of univariate logistic analysis show that the odds for the relocation were lower in workers with a recognized disability category $(\mathrm{OR}=0.5 ; 95 \% \mathrm{Cl} 0.2$ to 1.1$)$ than in those without a disability category, and in those who were on long-time sick leave (sick leave $\geq 30$ days: $\mathrm{OR}=0.31$; $95 \% \mathrm{Cl} 0.11$ to 0.88 ), in comparison with the workers without long-time sick leave.

\subsection{The Second Case Control Study: Termination of Employment Relationship}

\subsubsection{Descriptive Statistics}

The average age of the dismissed workers (cases) was 51, and the average employment period was 31 years, almost 27 years in the company. At the time of the termination of the employment contract, the average employment period of the controls of the dismissed workers was almost 32 years, and the average duration of the employment in the company was almost 26 years.

In the observed period, $63 \%$ of the dismissed workers and $68 \%$ of the controls were on sick leave. There are no significant differences between the dismissed workers and controls in the share of workers who were on sick leave (Table 4) and in the frequency and duration of total sick leave. On the contrary, the level of seriousness of total sick leave is significantly $(p<0.001)$ higher in dismissed workers, and the same holds true for the share of workers who were on long-time sick leave (sick leave $\geq 30$ days) $(p<0.001)$.

Table 4. Cases (dismissed workers) and controls by percentage of sick leave restriction of workability, proposal for the assessment of the remaining workability and disability category.

\begin{tabular}{|c|c|c|c|c|c|}
\hline \multirow[b]{2}{*}{ VARIABLE } & \multicolumn{2}{|c|}{$\begin{array}{l}\text { RELOCATED } \\
(\mathrm{n}=70)\end{array}$} & \multicolumn{2}{|c|}{$\begin{array}{l}\text { DISMISSED } \\
(\mathrm{n}=280)\end{array}$} & \multirow[b]{2}{*}{$p$ Value } \\
\hline & $n$ & $\%$ & $n$ & $\%$ & \\
\hline Sick leave & 44 & 62.9 & 191 & 68.2 & 0.393 \\
\hline $\begin{array}{l}\text { Restriction of } \\
\text { workability }\end{array}$ & 37 & 52.9 & 71 & 25.4 & $<0.001$ \\
\hline $\begin{array}{l}\text { Proposal for the } \\
\text { assessment of } \\
\text { workability }\end{array}$ & 22 & 31.5 & 9 & 3.2 & $<0.001$ \\
\hline Disability category & 30 & 42.9 & 33 & 11.8 & $<0.001$ \\
\hline
\end{tabular}

There are no significant differences between the dismissed workers and the controls in the frequency, duration and seriousness of sick leave $\leq 5$ days. In comparison to the controls, a significantly higher frequency and duration of sick leave $\geq 30$ days can be observed in the dismissed workers $(p<0.001)$.

In the dismissed workers, the restrictions of workability, proposals for the assessment of the remaining workability and the already recognized disability category are significantly higher $(\mathrm{p}<0.001)$ (Table 4$)$.

\subsubsection{Univariate Logistic Regression Analysis}

The results of univariate logistic analysis show that the risk for the termination of the employment was more than 4 times greater in workers on long-time sick leave (sick leave $\geq 30$ days), compared to those without sick leave $\geq 30$ days; more than 3 times higher in workers with limited workability, compared to those without restriction of workability; and more than 6 times greater in workers with disability category than in those without disability category. The highest risk for the termination of the employment relationship was faced by the workers with a proposal for the assessment of the remaining workability $(\mathrm{OR}=15.77 ; 95 \% \mathrm{Cl} 5.94$ to 41.88$)$ in comparison to the workers without a proposal for the assessment of the remaining workability (Table 5). 
Table 5. Odds ratio $(\mathrm{OR} ; 95 \% \mathrm{Cl})$ for the termination of employment relationship in dismissed workers, univariate logistic analysis.

\begin{tabular}{llcc}
\hline & OR & $95 \% \mathrm{Cl}$ & $\mathrm{p} \mathrm{Value}$ \\
\hline Sick leave & 0.79 & 0.45 to 1.36 & 0.390 \\
Sick leave $\leq 5$ days $\dagger$ & 0.62 & 0.36 to 1.04 & 0.070 \\
Sick leave $\geq 30$ days $\neq$ & 4.32 & 2.08 to 8.96 & $<0.001$ \\
Restriction of workability & 3.51 & 1.99 to 6.20 & $<0.001$ \\
Proposal for the assessment of workability & 15.77 & 5.94 to 41.88 & $<0.001$ \\
Disability category & 6.51 & 3.33 to 12.72 & $<0.001$ \\
Frequency of sick leave $\leq 5$ days & 1.05 & 0.94 to 1.18 & 0.421 \\
Duration of sick leave $\leq 5$ days & 1.02 & 0.95 to 1.08 & 0.636 \\
Seriousness of sick leave $\leq 5$ days & 0.86 & 0.59 to 1.29 & 0.465 \\
Frequency of sick leave $\geq 30$ days & 3.42 & 1.85 to 6.34 & $<0.001$ \\
Duration of sick leave $\geq 30$ days & 1.01 & 1.00 to 1.02 & $<0.001$ \\
Seriousness of sick leave $\geq 30$ days & 1.00 & 0.99 to 1.01 & 0.914 \\
\hline
\end{tabular}

†Sick leave $\leq 5$ days: cases of sick leave that lasted equal to, or fewer than, five days

$\ddagger$ Sick leave $\geq 30$ days: cases of sick leave that lasted for thirty days or more

\subsubsection{Multivariate Logistic Regression Analysis}

Further data processing was aimed at establishing the mutual influence of variables on the odds for the termination of the employment relationship. In the analyses, the effect was adjusted for the termination of employment in multivariate models, adding independent variables (sick leave $\leq 5$ days, sick leave $\geq 30$ days, restriction of workability, proposal for the assessment of workability, disability category and frequency of sick leave $\geq 30$ days) separately in the subsequent models, and finally, the full model including all independent variables and age. The odds for the termination of the employment is best described by the reduced model with two variables (sick leave $\geq 30$ days and the restriction of workability): workers who are on sick leave $\geq 30$ days have four times higher odds to be dismissed than those without long-time sick leave, if the occupational doctor has proposed the restriction of workability $(\mathrm{OR}=4.16 ; 95 \% \mathrm{Cl} 1.91$ to 9.07$)$ (Table 6).

Table 6. Odds ratio $(\mathrm{OR} ; 95 \% \mathrm{Cl})$ for the termination of employment relationship in dismissed workers, multivariate logistic analysis.

\begin{tabular}{cccc}
\hline & OR & $95 \% \mathrm{Cl}$ & $\mathrm{p}$ Value \\
\hline Sick leave $\geq 30$ days & & & \\
No & 1.00 & & \\
Yes & 4.16 & 1.91 to 9.07 & $<0.001$
\end{tabular}

Restriction of workability

$\begin{array}{lll}\text { No } & 1.00 & \\ \text { Yes } & 3.37 & 1.87 \text { to } 6.09<0.001\end{array}$

Sick leave $\geq 30$ days: cases of sick leave that lasted for thirty days or more The introduction of dummy variables did not yield better results.

\section{DISCUSSION}

The majority of the workers in the study were relocated to new workplaces in 2009, which coincided with the emergence of recession and with the closure of the plant (December 31, 2008). The majority of the workers were dismissed in 2010, which was a consequence of the planned restructuring of the company (January 1, 2011) as well as of the planned pension scheme reform in 2011 (Table 1).

The results show that of all the observed indicators of workers' health, long-time sick leave (sick leave $\geq 30$ days) and disability category exert the greatest influence on the employer's decision concerning the choice of workers (relocation or dismissal). Workers who were on sick leave $\geq 30$ days, as well as those with a recognized disability category, have lower odds to be relocated to a new workplace and higher odds to be dismissed. The results support the findings that long-time sick leave increases the risk for job termination, short- and longterm unemployment, and that longer sick leave in the period before the restructuring of a company, affects the dismissal of workers (11-16).

The decision about relocation of workers to new workplaces is affected only by long-time sick leave (sick leave $\geq 30$ days), whereas the dismissal is also influenced by the frequency and duration of sick leave $\geq 30$ days. The more frequent long time sick leave, the higher the odds that the worker will be dismissed. The results support the findings that frequent absences amounting to 6 weeks or more represent a risk for involuntary job termination (17). Despite that, the seriousness of an individual case 
of sick leave $\geq 30$ days does not influence the employer's decision about the relocation and dismissal of workers. The results show that in cases of long uninterrupted sick leave, which is the result of an important damage to health, and which is best described by the seriousness of sick leave, the employer does not decide for the change in the employment relationship. In the case of seriously ill workers, this means that in comparison with those who are not ill, they are not exposed to greater risks of being dismissed. The fact that longer sick leave in the case of a serious disease does not increase the risk for dismissal is also confirmed by the study carried out by Magee (18). Sick leave longer than 30 days is paid by the Health Insurance Institute of Slovenia, rather than by the employer, and is quite similar to disability.

Our results confirm the finding that disabled persons are often the first to lose the job in a company that is undergoing the process of restructuring, and are the last to be re-employed when the company is back on track $(19,20)$.

The results show that other indicators of workers' health (restriction of workability, proposal for the assessment of workability) exert influence only on the dismissal of workers, while they are not supposed to have influence on the relocation. There are several presuppositions as to why this claim was not confirmed. One of them is that the employer's decision is most certainly affected by other factors that have not been researched in our study and are unknown to us.

Long-time sick leave (sick leave $\geq 30$ days), restrictions of workability, proposal for the assessment of the remaining workability and the disability category represent risk factors for the termination of the employment relationship. Calculations show that the odds for the dismissal of a worker are the highest if the worker is on sick leave for more than 30 days, and if the occupational doctor has written a proposal for the assessment of workability by the Invalidity Committee.

The results of the study show that an occupational doctor's opinion primarily affects the dismissal rather than the relocation of workers, which is reflected in the withdrawal of a worker with restrictions from the labour market and a reduction of his/her employment possibilities. The adoption of a new pension scheme reform, which has prolonged the working life, only adds to the problem of the employment of workers with medical restrictions. It is a well-known fact that older workers suffer from more chronic diseases, which can exert an important influence on workability, and demand certain health restrictions at work. The increase in the number of older workers with health restrictions could be reflected in the increase in unemployment, which is already very high in the population aged 50 or more, and which increases social vulnerability and exclusion of the older population (21).
The study therefore shows that the indicators of a health status exert influence on the employer's decision-making in the process of the restructuring of a company, which indicates the selection of workers according to their health status. This is a direct form of health selection caused by the presence of a disease (and/or its consequences) which prevents the performance of the same work $(1,22-24)$. The selection on the basis of a health status can be discriminatory when an individual is treated less favourably independently of his/her productivity due to a certain unfavourable and/or undesired characteristic (among them being disease and disability) (25).

\subsection{Strengths and Limitations}

The strengths of this study are: the size of the enterprise, the number of the participants and the well-documented data.

This is the first study evaluating the effect of the approved occupational doctor's certificate (medical certificate) on the employer's decision-making (relocation/dismissal) during personnel restructuring in the enterprise, and testing the combination of the observed indicators of workers' health on it. The originality of the study also lies in the fact that, in the group of 'survivors of a restructuring programme,' we observe and recognize how the employer's decision to relocate someone was influenced by their health.

The study has a special value due to its performance in the ongoing financial crisis, in which dealing with the market makes employers less sensitive to workplace discrimination.

The limits of our study pertain to the fact that other circumstances also have an influence on the decision about the relocation or dismissal of workers. Presumably, the dismissal also greatly depends on the subjective decision of an employer. Those factors have not been researched. Neither have we investigated whether the workers have any influence on the outcome of the personnel restructuring. These circumstances cannot possibly be measured objectively, and it is likely that they affect the final results. If this be so, this influence is undifferentiated and, as such, it should not have a directing effect on the results gained.

Despite the fact that the lists of relocated workers were checked in cooperation with the human resources department, it is possible that we did not take into consideration the 'real' relocation of those workers who had been relocated several times. It is believed that the influence of a possible error relating to the classification is restricted as the same workers are studied, and only the observed period changes. If such an error had an actual effect, this effect could be limited to the calculation of sick leave. 
We estimated that the selection of a typical public limited company is not biased and does not have influence on the limitations of the study. Researchers are not employed in that enterprise, and the enterprise is representative of a typical public limited company in Slovenia with more than 1000 employees.

Further research is needed to determine more objective prognostic indicators which influence the relocation and the dismissal of workers, and to find out how those indicators affect employees in a small to medium-sized enterprise. A smaller number of employees mean that the employer has fewer opportunities to consider health limitations of workability.

\section{CONCLUSIONS}

The aim of the study was to find out how health indicators accessible to the employer influence the employer's decision concerning the selection of workers (relocation of the workers and dismissal for business purposes) during personnel restructuring in the enterprise.

The study was based on researching workers' health status as a possible criterion for the selection. The mechanism for health selection is a reduction of productivity in relation to illness (direct selection) or certain health behaviour (indirect selection) (1).

The study proves that those objective indicators of workers' health which are accessible to the employer (sick leave, approved occupational doctor's opinion and disability category) are important criteria for direct health selection and a basis for the discrimination in the workplace during personnel restructuring in the enterprise.

Despite the differences between sickness benefit, estimation of health-related workability and work-related disability, we believe that the results of the study will gain recognition regarding the influence of workers' health on their socio-economic status.

The value of the study for occupational medicine is in that it is raising the awareness of discriminatory issues in medical certification after preventive medical checkups, and in that it represents a starting point for avoiding that. According to the present legislation, occupational doctors are experts in the area of the assessment of workability. The employers choose them themselves and sign contracts with them. Such a position most certainly does not encourage expert independence of occupational doctors, since they are available 'on the market' and compete for services. If the results of the study were added which would indicate discriminatory effects of an authorized doctor's opinion on the employment status, we could understand what kind of ethical dilemmas occupational doctors are faced with on a daily basis when reaching decisions on workability.

In the future, it would be sensible to settle the status of occupational doctors, primarily in terms of their economic independence from the employers (workers' insurance company).

The results of the study might also interest the doctors (general practitioners and doctors employed in The Health Insurance Institute of Slovenia) who have authority to issue sickness certificates.

To conclude, our findings might be of importance for those who monitor discrimination in the workplace on the basis of an employee's health, and for all policy stakeholders interested in employing people with disability and retirement planning policy.

\section{CONTRIBUTORS}

AM and MDF designed the hypothesis, analysed the data and wrote the paper.

\section{CONFLICTS OF INTEREST}

The authors declare that no conflicts of interest exist.

\section{FUNDING}

None.

\section{ETHICAL APPROVAL}

Not required.

\section{REFERENCES}

1. Jusot F, Khlat M, Rochereau T, Serme C. Job loss from poor health, smoking and obesity: a national prospective survey in France. J Epidemiol Community Health 2008; 62: 332-7.

2. Tunceli K, Bradley CJ, Nerenz D, Williams LK, Pladevall M, Elston Lafata J. The impact of diabetes on employment and work productivity. Diabetes care 2005; 28: 2662-7.

3. Su J, Brook RA, Kleinman NL, Corey-Lisle P. The impact of hepatitis C virus infection on work absence, productivity, and healthcare benefit costs. Hepatology 2010; 52: 436-42.

4. Bartley M, Ferrie J. Glossary: unemployment, job insecurity and health. J Epidemiol Community Health 2001; 55: 776-81.

5. Marmot M, Feeney A, Shipley M, North F, Syme SL. Sickness absence as a measure of health status and functioning: from the UK Whitehall II study. J Epidemiol Community Health 1995; 49: 124-30.

6. Kivimäki M, Head J, Ferrie JE, Shipley MJ, Vahtera J, Marmot MG. Sickness absence as a global measure of health: evidence from mortality in the Whitehall II prospective cohort study. BMJ 2003; 327: 364 . 
7. Head J, Ferrie JE, Alexanderson K, Westerlund H, Vahtera J, Kivimäki $M$. Whitehall II prospective cohort study: diagnosis-specific sickness absence as a predictor of mortality: the Whitehall II prospective cohort study. BMJ 2008; 2: 337.

8. Ferrie JE, Vahtera J, Kivimäki $M$, Westerlund $H$, Melchior $M$, Alexanderson $\mathrm{K}$. et al. Diagnosis-specific sickness absence and allcause mortality in the GAZEL study. J Epidemiol Community Health 2009; 63: 50-5.

9. Kivimäki M, Head J, Ferrie JE, Singh-Manoux A, Westerlund H, Vahtera J. et al. Sickness absence as a prognostic marker for common chronic conditions: analysis of mortality in the GAZEL study. Occup Environ Med 2008; 65: 820-6.

10. Vahtera J, Kivimaki M, Pentti J. The role of the extended weekends in sickness absenteeism. Occup Environ Med 2001; 58: 818-22.

11. Virtanen M, Kivimäki M, Vahtera J. et al. Sickness absence as a risk factor for job termination, unemployment, and disability pension among temporary and permanent employees. Occup Environ Med 2006; 63: 212-7.

12. Strully K. Job loss and health in the U.S. labor market. Demogrphy 2009; 46: 221-46

13. Hultin $\mathrm{H}$, Lindholm C, Möller J. Is there an association between longterm sick leave and disability pension and unemployment beyond the effect of health status?: a cohort study. PLoS One 2012; 7: e35614.

14. Haahr JP, Frost P, Andersen JH. Predictors of health related job loss: a two-year follow-up study in a general working population. J Occup Rehabil 2007; 17: 581-92.

15. Szubert Z, Sobala W. Sickness absence in persons who leave their jobs due to various reasons. Med Pr 2003; 54: 555-62.

16. Vahtera J, Kivimäki M, Pentti J, Linna A, Virtanen M, Virtanen P. et al. Organisational downsizing, sickness absence, and mortality: 10-town prospective cohort study. BMJ 2004; 328: 555.
17. Koopmans PC, Roelen CA, Groothoff JW. Frequent and long-term absence as a risk factor for work disability and job termination among employees in the private sector. Occup Environ Med 2008; 65: 494-9.

18. Magee W. Effects of illness and disability on job separation. Soc Sci Med 2004; 58: 1121-35.

19. Kruse D, Schur L. Employment of people with disabilities following the ADA. Industrial Relations 2003; 42: 31-64.

20. Kaye HS. The impact of the 2007-09 recession on workers with disabilities. Monthly Labor Review 2010; 10: 19-30.

21. Registirana brezposelnost po območnih enotah Zavoda Republike Slovenije za zaposlovanje in uradih za delo. Available October 28, 2014 from: http://www.ess.gov.si/trg_dela/trg_dela_v_stevilkah/ registrirana_brezposelnost\#Slovenija

22. Guthrie R, Westaway J. Emerginig legal concerns with chronic diseases in the Australian workplace: pre-employment medicals, functional capacity evaluations, workers compensation and disability discrimination. J. Law Med 2009; 16: 803-21.

23. Park JH, Park EC, Park JH, Kim SG, Lee SY. Job loss and re-employment of cancer patient in Korean employees: a nationwide retrospective cohort study. J Clin Ocol 2008; 26: 1302-9.

24. Andrén D. Long-term absenteeism due to sickness in Sweden: how long does it take and what happens after? Eur J Health Econ 2007; 8: $41-50$.

25. Leino Arjas P, Liira J, Mutanen P, Malmivaara A, Martikainen E. Predictors and consequences of unemployment among construction workers: prospective cohort study. BMJ 1999; 319: 600-5. 